\title{
Melt Inclusions Suggest Top-Down Control on Eruptive Style at Masaya Volcano
}

\author{
L. HLINKA1,2, M.-A. LONGPRÉ 1,2, W. PÉREZ 3,
}

\author{
S. KutTERolF3, B. MONTELEONE4
}

1The Graduate Center, CUNY, New York, NY 10016 USA

(*correspondence: 1hlinka@gradcenter.cuny.edu)

2Queens College, CUNY, Flushing, NY 11367, USA

3 GEOMAR, Helmholtz Centre for Ocean Research, Kiel, Germany

4Woods Hole Oceanographic Institution, Woods Hole, MA 02543 USA

Masaya volcano, Nicaragua, is one of the few basaltic volcanoes on Earth to have generated a wide range of eruptive styles from effusive lava lake activity to voluminous ignimbrites, surges, and Plinian fall deposits. Prior work [1] has shown an overall compositional homogeneity of the magmatic system over $>30,000$ years, and inferred that the volcano is underlain by a massive $>10 \mathrm{~km} 3$ open-system basaltic magma reservoir at $\sim 1 \mathrm{~km}$ depth. Due to its unique history, Masaya is an ideal case study to better constrain the primary controls on eruptive style at basaltic volcanoes. Here we analyze matrix glasses and melt inclusions hosted in olivine, plagioclase, and clinopyroxene crystals from lava lake (LL) ejecta and two Plinian deposits-the 2.1 ka Masaya Triple Layer (MTL) and the $1.7 \mathrm{ka}$ Ticuantepe Lapilli (TIL)-for major, trace, and volatile $\left(\mathrm{CO}_{2}, \mathrm{H}_{2} \mathrm{O}, \mathrm{S}, \mathrm{Cl}, \mathrm{F}\right)$ element concentrations to test whether pre-eruptive volatile contents may be linked to eruptive style. We find that melt inclusions from lava lake and Plinian tephras show systematic differences in preeruptive volatile contents, forming distinct groups with mean $\mathrm{H}_{2} \mathrm{O}$ values of $0.6 \mathrm{wt} . \%$ in LL, $1.1 \mathrm{wt} . \%$ in MTL, and $1.9 \mathrm{wt} . \%$ in TIL samples. Together, these groups generate positive correlations between $\mathrm{S}, \mathrm{Cl}$ and $\mathrm{H}_{2} \mathrm{O}$ concentrations, with maximum values reaching $920 \mathrm{ppm}, 1300 \mathrm{ppm}$ and 2.3 wt.\%, respectively, which are low with respect to typical maxima for Central American arc magmas [2]. Correspondingly, calculated volatile saturation pressures are also low, with means of $52 \pm 33,66 \pm 35$, and $96 \pm$ $47 \mathrm{MPa}$ for LL, MTL TIL samples, respectively. These observations, coupled with clear evidence for $\mathrm{Cl}$ exsolution during second boiling, demonstrate that, regardless of the ultimate eruption style, Masaya magmas undergo various, but extensive pre-eruptive degassing in a shallow $(<4 \mathrm{~km})$ reservoir. Initial magma composition and anomalously high volatile contents can be excluded as primary controls on eruptive style at Masaya. Instead, our results suggest a top-down control on eruptive style whereby temporary sealing of the system may be sufficient to transition to explosive behavior. There may thus be a thin line between open-conduit conditions and Plinian eruptions at Masaya.

[1] Walker et al. (1993) J. Volcanol. Geotherm. Res. 56, 379-400.

[2] Sadofsky et al. (2007) Contrib. Mineral. Petrol. 155, 433-456. 